\title{
肝細胞癌に対する経皮的低出力マイクロ波腫蝪凝固療法の検討
}

$$
\text { 澤村明廣青儀健二郎南一仁峠哲哉 }
$$

\section{Usefulness of percutaneous microwave tissue coagulation therapy for small hepatocellular carcinoma}

\author{
Akihiro Sawamura, Kenjiro Aogi, Kazuhito Minami and Tetsuya Toge
}

\begin{abstract}
The possible use of percutaneous transhepatic microwave tissue coagulation therapy (PMCT) using ultrasonography under local anesthesia for small solitary hepatocellular carcinoma was studied.

The subjects were 7 patients having primary or reccurent hepatocellular carcinoma with solitary liver tumor less than $3 \mathrm{~cm}$ in size, consisting of 4 primary and 3 reccurent hepatocellular carcinoma, PMCT was performed continuously 3 times at the out put of 30 watts for 30 seconds at time. Tumor was completely coagulated by irradiation from 2 to 6 times judged by enhanced CT.

No reccurence of tumor was recognized in the coagulation area. Thus, the results suggest that PMCT is a useful therapy for small hepatocellular carcinoma as a local control.
\end{abstract}

Key words: percutaneous transhepatic microwave coagulation therapy (PMCT), small hepatocellular carcinoma

Accepted on July 29, 1998

広島大学原爆放射能医学研究所腫瘍外科 干 734-8553 広島市南区霞1-2-3

Department of Surgical Oncology, Research Institute for Radiation Biology and Medicine, Hiroshima University

Address: 1-2-3, Kasumi, Minami-ku, Hiroshima city, 734-8553, Japan 


\section{はじめに}

経皮的マイクロ波腫瘍凝固療法の適応拡大のために， 局所麻酔下での経皮的マイク口波腫瘍凝固療法 （PMCT）の基礎的検討を行い，その結果を報告して きた ${ }^{1)-3)}$ 。本稿では肝細胞癌に対する臨床応用の有用 性について述べる。

\section{$I$ 。対象と方法}

1. 対象

1994 年 9 月から 1997 年 5 月までの期間に当科に入院 された径 $3 \mathrm{~cm}$ 以下の孤立性肝細胞癌の 7 例を対象とし た。

\section{2. 方法}

ベッドサイドで局所麻酔下に，マイクロ波の出力を 30 ワット，放射時間を 30 秒で 3 連続放射を 1 回として, エコーガイド下に腫瘍が完全に凝固されるまで繰り返 し行った。電極は18Gの深部用を使用した²。

\section{II. 凝固範囲の評価方法}

凝固範囲の判定は造影 CTにて行った。すなわち， 均一なlow density areaとして描出される部分で，な おかつその範囲が術前の腫瘍の範囲を越えていた場合 には完全凝固，少しでも造影される部分が遺残してい た場合，あるいは均一な low density areaであっても その範囲が術前の腫㒵の範囲より小さい場合には非凝 固と判定した

\section{III. 結果}

腫瘍の局在は $\mathrm{S}_{1}, 4$ は経験していないがエコーで確認 できる部位であれば凝固可能であった。原発性の場合， 手術拒否が 1 例いたが，その他は肝硬変合併症例であ った。再発症例の3例はすべて肝切除症例であった。6 例は 1 回の操作で 2 6 回の焼灼を行い完全凝固が得ら れた。症例 6 の 1 例のみが 1 回の操作で 3 回焼灼し不完 全凝固と判断され，1週後に 2 回焼灼し，完全凝固が得 られた（表1）。

表1。対象

\begin{tabular}{|c|c|c|c|c|c|c|}
\hline & 症例 & 腫瘍局在 & 非手術の理由 & 腫場長径（cm） & 焼灼回数（回） & 評価 \\
\hline \multirow{4}{*}{ 原発 } & 1. $78 / \mathrm{F}$ & S3 & 肝硬変 & 2.9 & 4 & N.D. ${ }^{*}$ \\
\hline & 2. $67 / \mathrm{F}$ & $\mathrm{S}_{7}$ & 肝硬変 & 3.0 & 5 & good \\
\hline & 3. $98 / \mathrm{F}$ & S8 & 肝硬変 & 2.5 & 6 & good \\
\hline & 4. $49 / \mathrm{M}$ & $\mathrm{S}_{2}$ & 手術拒否 & 3.0 & 6 & good \\
\hline \multirow{3}{*}{ 再発 } & 5. $65 / \mathrm{M}$ & S6 & 朋切後 & 1.4 & 3 & good \\
\hline & 6. $57 / \mathrm{M}$ & $\mathrm{S}_{2}$ & 肝切後 & 2.0 & 5 & good \\
\hline & 7. $62 / \mathrm{M}$ & $\mathrm{S}_{3}$ & 肝切後 & 1.0 & 2 & good \\
\hline
\end{tabular}

表2.PMCT後の無再発期間

\begin{tabular}{|c|c|c|c|c|c|c|c|}
\hline & 症例 & 無再発期間（力月） & 合併症 & 凝固後の無再発期間（力月） & 再発部位 & 凝固後 & 予後 \\
\hline \multirow{4}{*}{ 原発 } & 1. $78 / \mathrm{F}$ & - & なし & 5 & $\mathrm{~S} 7,8$ & 21 力月 & 死 \\
\hline & 2. $67 / \mathrm{F}$ & - & なし & 19 & なし & 19 力月 & 生 \\
\hline & 3. $98 / \mathrm{F}$ & - & 肝障害（軽度） & 9 & $\mathrm{~S} 7$ & 10 力月 & 生 \\
\hline & 4. $49 / \mathrm{M}$ & - & 肝障害（軽度） & 12 & なし & 12 力月 & 生 \\
\hline \multirow{3}{*}{ 再発 } & 5. $65 / \mathrm{M}$ & 12 & 肝障害（軽度） & 8 & なし & 8 力月 & 生 \\
\hline & 6. $57 / \mathrm{M}$ & 8 & 肝障害（軽度） & 7 & $\mathrm{~S} 4,3$ & 18 力月 & 死 \\
\hline & 7. $62 / \mathrm{M}$ & 50 & なし & 6 & なし & 6 力月 & 生 \\
\hline
\end{tabular}


合併症は 7 例中 4 例に軽度の肝障害が認められたが， 全例, 術後 3 日で術前の值に期していた。再発が認め られたものの凝固後の無再発期間は最短で 5 力, 最 長で 19 力であった。現時点で無再発で経過している ものは 4 例であった。再発は 3 例に認められたが，全 例凝固部位とは違う区域であった（表2）。凝固局所は よくコントロールされていたが，1例において他部位 に多発性に再発が認められた。凝固後, まだ経過が短 いために，予後に対する有効性は現時点では論じられ ない。

\section{$I V$ 。考察}

肝細胞癌の場合，肉眼的に肝内転移が認められない 場合でも結節の近傍に組織学的な転移の発見されるこ とが $30 \%$ 前後はあると考えられる5)。このため, 肝細 胞癌の治療法としては，これらを完全に制御するため には車区域以上の外科的切除が第一に選ばれる治療法 であると考えられる ${ }^{6)}$ 。しかしながら，90\%以上の症 例が肝障害を伴っていることから，肝細胞癌において 約半数は縮小手術を行わざるを得ないのが現状である。 したがって, 腫瘍核出術あるいは部分切除になる場合 には熱凝固療法のよい適応になると考えられる。

経皮的なアプローチの場合, 深部用電極が開発され た当時は電極も $12 \mathrm{G}$ と太全身麻酔下に行われていた。 この場合， $2 \mathrm{~cm}$ までの腫瘍がこの適応になると思われ る。

経皮的な場合にはいまだ手技上の熟練が必要である。 60 ワット，40秒以上の高出力で焼灼すると炭化を伴い 完全燒灼されるが，焼灼中はバブリングといわれる水 分の蒸発が起こるために，燒灼中は超音波にて焼灼範 囲を観察することが不可能であり，術者の熟練により 腫瘍を焼灼してきたのが実状である。またこれほど の高出力で経皮的に焼灼した場合には，全身麻酔下で ないと患者の痛みが強く, さらには穿刺部皮膚の火傷 の原因にもなる。

以上のことから，PMCTは術者の熟練度によりその 凝固効果が左右されていたために，その効果の割には 広く普及していなかったと考えられる。
われわれが考案した低出力でのPMCTは30ワット， 30 秒，3回連続照射にて高出力でのPMCTと同等の $20 \times 10 \mathrm{~mm}$ の凝固範网が得られること，局所麻酔で除 痛ができること，バブリングが起こらず焼灼中，超音 波にて凝固範囲が観察可能であることから，局所麻酔 下で，エコーガイド下に経皮的マイクロ波腫瘍凝固療 法が可能となった。また，われわれの基礎的検討では， たとえ低出力でも肉眼的に色調変化が認められる範囲 は核染色により核の破壊が確認されており，完全に凝 固されているものと判断された ${ }^{4)}$. 合併症としてはほ とんどの症例で凝固翌日に一過性の軽度の肝障害が認 められたが全例 3 日後には凝固前の值に帰した。その ほかには今のところ重篤な合併症は経験していない。

大きさでは径が $3 \mathrm{~cm}$ を越えるものでは，少なくとも 11 回以上の焼灼が必要となり，完全な凝固が得難くな る ${ }^{4}$ 。また超音波検査にて脈管侵襲があると判断でき るものはかなり中枢に腫瘍が存在しておりここの部を 焼灼すると胆管狭窄を起こす可能性がある7)。

このため, 低出力でのエコー下経皮的マイクロ波凝 固療法の適応を以下に定めた。

(1)㧓立性であること

(2)径 $3 \mathrm{~cm}$ 以下の腫瘍であること

(3)超音波検査上脈管侵襲のないもの

今後は症例を重ね，予後に対する有効性の評価をす る必要性があると思われる。

\section{結語}

肝細胞癌に対する細径電極を用いた低出力による PMCTは局所麻酔下にて施行できること，バブリング の発生がないために，焼灼中エコーにて凝固範囲が観 察できること，などの利点が考えられる。しかしなが ら，凝固局所のコントロールは良好であるが，他部位 の再発予防には無力である。したがって，分化度など により朋動注療法の併用の必要性があると思われた。 


\section{References}

1）澤村明廣, 吉本晃宏, 武田晋平, 青儀健二郎, 船越真人, 平井敏弘, 䟔 哲哉: 新しい電極を用いた経皮的マイクロ 波腫瘍凝固療法の基礎的検討. J Microwave Surg $12: 9$ 12,1994

2）吉本晃宏, 澤村明廣, 青儀健二郎, 峠 哲哉, 国安弘基, 田原栄一：マイクロ波凝固による病理組織学的変化と細胞 活性. J Microwave Surg $14:$ 17-22, 1996

3）澤村明廣, 青儀健二郎, 吉本晃宏, 峠 哲哉: Bedside treatmentとしての経皮的マイクロ波腫瘍凝固療法。J Microwave Surg 14:43-48, 1996

4) 澤村明廣, 宮原栄治, 青儀健二郎, 檜原 淳, 野間浩介,
南一仁, 吉田和弘, 山口佳之, 峠 哲哉: 孤立性肝癌に 対する局麻下経皮的マイクロ波腫瘍凝固療法の検討. 癌と 化学療法 $24 ： 1643-1646,1997$

5）山中若樹, 岡本英三：外科からみた肝細胞癌の治療方針. 外科診療 $33: 297-301,1996$

6）厚生省：平成 6 年度厚生省がん研究助成金による研究報告 書「肝臓の微小がんに関する基礎的, 臨床的研究」（主任研 究者・坂元亭宇)。43-49, 1995

7）児玉久光：転移性肝癌に対するマイクロ波メスを応用した 腫瘍凝固療法の基礎的・臨床的検討. 広大医誌 36 : 193206, 1988 